\title{
STREPTOCOCCAL AGGLUTININS IN PATIENTS WITH RHEUMATOID (ATROPHIC) ARTHRITIS AND ACUTE RHEUMATIC FEVER
}

\author{
BY CHESTER S. KEEFER, WALTER K. MYERS AND \\ THEODORE W. OPPEL \\ (From the Thorndike Memorial Laboratory, Second and Fourth Medical Services (Harvard), \\ Boston City Hospital and the Department of Medicine, Harvard Medical School, \\ Boston)
}

(Received for publication October 11, 1932)

The diagnosis of an infectious disease may be determined by three general methods: (1) the observation of clinical features so distinctive that the disease is recognized by the history or by the physical examination, as in smallpox or chicken pox; (2) the use of a characteristic diagnostic test, such as the Wassermann reaction in syphilis or the Weil-Felix reaction in typhus fever; (3) the isolation of the specific exciting cause as the culture of the etiologic agent in the case of typhoid fever.

In the case of rheumatoid arthritis ${ }^{1}$ there is no general agreement regarding a specific exciting cause, since no one organism has been isolated consistently by all observers who have made cultures of the blood, of the joint fluid, of the joint tissues or of the subcutaneous fibroid nodules. At the present time there is no characteristic diagnostic test available which will assist in establishing an etiologic diagnosis in each case. In recent years, however, various observers have pointed out that a high percentage of patients with rheumatoid arthritis possess agglutinins in their blood serum against various strains of hemolytic streptococci. If one were able to ascertain by means of agglutination tests the cases in which streptococci were in some way responsible for the disorder of the joints, it would be of great help in distinguishing between cases. In order to determine whether the blood of patients with rheumatoid arthritis and rheumatic fever had agglutinins for hemolytic streptococci in a higher percentage of cases than other diseases, we have made 1205 agglutination tests in 332 patients, using four different strains. The cases are summarized in Table 1.

In any consideration of streptococcal agglutination tests the methods employed are of the highest importance, if information of value is to be obtained. It is necessary that the organism be grown diffusely and that it

${ }^{1}$ The term rheumatoid arthritis is used in this and subsequent papers, synonymously with atrophic arthritis. Degenerative arthritis is used synonymously with hypertrophic or osteoarthritis. 
does not agglutinate spontaneously. Heat-killed organisms should be used rather than live organisms, or organisms killed by formalin, because it has been shown by Tillett and Abernethy (1) that such antigens are unsuitable for agglutination tests. In the present investigation four strains of hemolytic streptococci were used. Two were scarlet fever strains, one was obtained from the throat of a patient with acute follicular tonsillitis, and the fourth was recovered from the blood of a patient with chronic arthritis, and was obtained from Dr. Stainsby. The organisms were grown for eight to twelve hours, in veal infusion broth of $\mathrm{pH} 7.2$, buffered with 0.2 per cent dibasic anhydrous sodium phosphate, and killed at $56^{\circ} \mathrm{C}$. for two hours. Dilutions of the sera were made so that the final dilutions of each varied from $1: 20$ to $1: 5120$. Organisms in broth, and in some cases in normal serum, were used as controls. The organisms and serum dilutions were incubated at $37^{\circ} \mathrm{C}$. for two hours, then placed in the icebox overnight and read the following morning. A test was called positive only when the organisms settled in clumps at the bottom of the tube leaving a clear supernatant fluid above, and if they remained in clumps following agitation.

The cases have been divided into various groups as summarized in Table 1. The disease in which positive agglutination tests were observed

TABLE 1

Results of agglutination tests using four different strains of hemolytic streptococci

\begin{tabular}{|c|c|c|c|c|c|c|c|c|c|c|c|}
\hline \multirow{2}{*}{ Disease } & \multirow{2}{*}{ 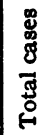 } & \multirow{2}{*}{ 莣 } & \multicolumn{9}{|c|}{ Highest dilution of sera in which agglutination occurred } \\
\hline & & & 1: & $\begin{array}{l}1: \\
40\end{array}$ & 1: & $\begin{array}{c}1: \\
160\end{array}$ & $\begin{array}{l}1: \\
320\end{array}$ & $\begin{array}{l}\text { 1: } \\
640\end{array}$ & $\begin{array}{c}1: \\
1280\end{array}$ & $\begin{array}{c}1: \\
2560\end{array}$ & 1: \\
\hline 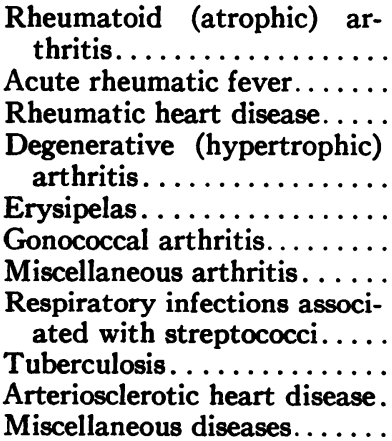 & $\begin{array}{l}22 \\
42 \\
31 \\
\\
28 \\
17 \\
14 \\
15 \\
44 \\
16 \\
28 \\
75\end{array}$ & $\begin{array}{l}4 \\
4 \\
0 \\
0\end{array}$ & $\begin{array}{l}0 \\
0 \\
0 \\
0 \\
0 \\
0 \\
0 \\
0 \\
0 \\
0 \\
0\end{array}$ & $\begin{array}{l}0 \\
2 \\
0 \\
0 \\
1 \\
0 \\
0 \\
0 \\
0 \\
0 \\
0\end{array}$ & $\begin{array}{l}0 \\
1 \\
0 \\
0 \\
0 \\
0 \\
0 \\
0\end{array}$ & $\begin{array}{l}4 \\
5 \\
2 \\
1 \\
0 \\
0 \\
0 \\
0 \\
0 \\
0 \\
0\end{array}$ & $\begin{array}{l}1 \\
3 \\
1 \\
1 \\
1 \\
0 \\
0 \\
0 \\
0 \\
0 \\
0\end{array}$ & $\begin{array}{l}3 \\
1 \\
0 \\
1 \\
1 \\
1 \\
0 \\
0 \\
0 \\
0 \\
0 \\
0\end{array}$ & $\begin{array}{l}0 \\
0 \\
0 \\
0 \\
0 \\
0 \\
0 \\
0 \\
0 \\
0 \\
0 \\
0\end{array}$ & $\begin{array}{l}0 \\
0 \\
0 \\
1 \\
0 \\
0 \\
0 \\
0 \\
0 \\
0 \\
0\end{array}$ & $\begin{array}{l}1 \\
0 \\
0 \\
0 \\
0 \\
0 \\
0 \\
0\end{array}$ \\
\hline
\end{tabular}

were rheumatoid arthritis, acute rheumatic fever, rheumatic heart disease, degenerative arthritis and erysipelas. They were not observed in the other diseases studied by us. In the group with rheumatoid arthritis, 192 agglutination tests with four different strains of hemolytic streptococci 
were done on twenty-two patients. Of these, twelve patients showed positive agglutinins to one or more of the strains used. In only one case was the titre above $1: 640$ and no one strain was agglutinated in higher dilutions than another. Tables 2 and 3 show the number of times the

TABLE 2

Results of agglutination with various strains of hemolytic streptococci

\begin{tabular}{|c|c|c|c|c|c|c|}
\hline \multirow{2}{*}{ Disease } & \multirow{2}{*}{$\begin{array}{l}\text { Total } \\
\text { cases }\end{array}$} & \multirow{2}{*}{$\begin{array}{c}\text { Total } \\
\text { positive } \\
\text { aggluti- } \\
\text { nations }\end{array}$} & \multicolumn{4}{|c|}{ Strains } \\
\hline & & & I & II & III & IV \\
\hline 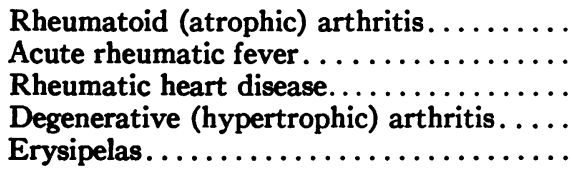 & $\begin{array}{l}22 \\
42 \\
31 \\
28 \\
17\end{array}$ & $\begin{array}{r}12 \\
11 \\
3 \\
4 \\
4\end{array}$ & $\begin{array}{r}10 \\
8 \\
1 \\
2 \\
4\end{array}$ & $\begin{array}{r}12 \\
9 \\
2 \\
2 \\
2\end{array}$ & $\begin{array}{r}11 \\
5 \\
1 \\
2 \\
1\end{array}$ & $\begin{array}{l}9 \\
\mathbf{5} \\
\mathbf{0} \\
\mathbf{0} \\
\mathbf{2}\end{array}$ \\
\hline
\end{tabular}

TABLE 3

Agglutination titre of serum of patients with rheumatoid (atrophic) arthritis

\begin{tabular}{r|c|c|c|c|c|c|c|c|c|c|c|c}
\hline \hline & \multirow{7}{*}{$\begin{array}{c}\text { Total } \\
\text { Sositive }\end{array}$} & \multicolumn{7}{c|}{ Dilutions } & Control \\
\cline { 3 - 10 } & & $1: 20$ & $1: 40$ & $1: 80$ & $1: 160$ & $1: 320$ & $1: 640$ & $1: 1280$ & $1: 2560$ & $1: 5120$ & \\
\hline I & 10 & 0 & 2 & 3 & 2 & 1 & 1 & 0 & 0 & 1 & 0 \\
II & 12 & 0 & 1 & 6 & 3 & 0 & 2 & 0 & 0 & 0 & 0 \\
III & 11 & 0 & 1 & 0 & 4 & 1 & 5 & 0 & 0 & 0 & 0 \\
IV & 9 & 0 & 2 & 0 & 3 & 1 & 3 & 0 & 0 & 0 & 0 \\
\hline
\end{tabular}

various strains were agglutinated and the highest dilutions of the sera showing positive agglutinins. From this data it would appear that the agglutination reaction is certainly not a strain-specific one, but rather a broad reaction to a number of strains of hemolytic streptococci. In some cases agglutinins were present over a period of several months; in others, they disappeared after a month or two. They were maintained or increased in several patients by intravenous vaccination with one strain. Figure 2 illustrates the effect of vaccination with one strain $\left(\mathrm{SD}_{1}\right)$ on the agglutination titre for that particular strain and for the other strains of streptococci used.

Eleven of the forty-two patients with rheumatic fever showed positive agglutinins at one or more times during the period of observation varying from one to six months. There were 273 examinations made but in no case did we observe agglutinins above $1: 640$ in the blood serum dilution (see Table 1). In most cases the positive reactions were observed only once or twice in the same individual during the period of observation. In a number of the cases the tests were repeated over a period of from one 
to four months and were persistently negative. In the cases in which a positive test was observed, it was usually present on one or two occasions and then became negative. As pointed out above, however, the titre of the serum was never very high.

Of the thirty-one patients with rheumatic heart disease, positive agglutination was observed in three cases. In two the agglutinations appeared following an acute follicular tonsillitis. The only other positive agglutinations we observed were in eleven patients with erysipelas, and in four patients with degenerative arthritis.

The recent observations of Tillett and Abernethy (1) are of great interest and importance in interpreting streptococcal agglutination tests. They have shown that sera from patients acutely ill with a variety of bacterial infections other than streptococcal are capable of agglutinating certain strains of hemolytic streptococci. The agglutinability was most striking when live organisms or organisms killed with formalin were used, but agglutinations did not occur if the cultures were heated to the thermal death point. Further, it was demonstrated that the protein fraction of the serum precipitated by water and carbon dioxide contains the constituent reactive with streptococci. In other words, one may obtain positive agglutination reactions to certain strains of hemolytic streptococci during the course of a number of acute infections not due to streptococci if one uses live or formalized antigens, but not when killed organisms are used. In our observations, we used only heat-killed organisms so that the type of agglutination described by Tillett and Abernethy seemed to be unlike that which we observed. In order to determine, however, whether the type of agglutination observed was different, and whether the constituent reactive to the killed streptococci was in the carbon dioxide precipitable fraction of the serum, we studied the agglutination reactions of several patients with positive agglutinins. Agglutination tests were performed with live organisms, heat-killed organisms, and formalin-killed cultures, using whole serum, the water and $\mathrm{CO}_{2}$ precipitable fraction of the serum, and the supernatant part of the serum after precipitating the protein with $\mathrm{CO}_{2}$ and water. The results are summarized in Table 4.

It is clear that these agglutination reactions were different from those observed by Tillett and Abernethy (1). In our cases agglutination was present in the whole serum and in the supernatant fluid following precipitation of the protein with $\mathrm{CO}_{2}$ in all cases in which it was tested. Agglutination was not observed when live organisms were used except in the case of one strain and one serum.

It was further pointed out by Tillett and Abernethy that the cases showing the most marked agglutination with live or formalized organisms, also showed a rapid sedimentation rate for the red blood corpuscles, and they suggested that the same mechanism was responsible for both 
phenomena. In order to determine whether the sedimentation rate of the erythrocytes could be correlated with the agglutination reactions in similar groups of disease, Figure 1 was constructed. In column A are

TABLE 4

Results of agglutination tests with strains $I$ and II in various fractions of blood serum from patients with positive agglutinins

\begin{tabular}{|c|c|c|c|c|}
\hline $\begin{array}{c}\text { Case } \\
\text { number }\end{array}$ & Strain & Whole serum & $\underset{\substack{\text { precipitable } \\
\text { fraction }}}{\mathrm{CO}_{2}}$ & $\begin{array}{l}\text { Supernatant } \\
\text { fluid }\end{array}$ \\
\hline \multirow{3}{*}{1.} & I & dilution & dilution & dilution \\
\hline & $\begin{array}{l}\text { Culture live } \ldots \ldots \ldots \ldots \ldots \ldots \ldots \\
\text { Culture heat-killed } \ldots \ldots \ldots \ldots \ldots \ldots \\
\text { Culture formalin-killed............ }\end{array}$ & $\begin{array}{l}\quad 0 \\
1: 1280 \\
1: 80\end{array}$ & $\begin{array}{c}0 \\
1: 20 \\
0\end{array}$ & $\begin{aligned} & 0 \\
1: & 640 \\
1 & : 80\end{aligned}$ \\
\hline & 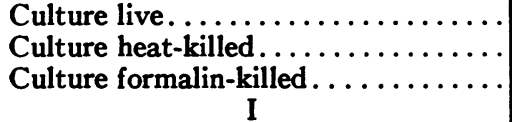 & $\begin{array}{l}0 \\
1: 640 \\
1: 80\end{array}$ & $\begin{array}{c}0 \\
1: 40 \\
0\end{array}$ & $\begin{array}{l}0 \\
1: 640 \\
1: 80\end{array}$ \\
\hline \multirow[t]{2}{*}{2.} & $\begin{array}{l}\text { Culture live } \ldots \ldots \ldots \ldots \ldots \ldots \ldots \\
\text { Culture heat-killed } \ldots \ldots \ldots \ldots \ldots \ldots \\
\text { Culture formalin-killed. } \ldots \ldots \ldots \ldots \ldots\end{array}$ & $\begin{array}{l}0 \\
1: \\
160 \\
0\end{array}$ & $\begin{array}{l}\mathbf{0} \\
\mathbf{0} \\
\mathbf{0}\end{array}$ & $\begin{array}{l}0 \\
1: 320 \\
0\end{array}$ \\
\hline & 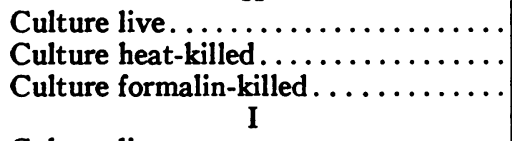 & $\begin{array}{l}0 \\
1: \begin{array}{l}160 \\
0\end{array}\end{array}$ & $\begin{array}{l}\mathbf{0} \\
\mathbf{0} \\
\mathbf{0}\end{array}$ & $\begin{array}{c}0 \\
1: 80 \\
0\end{array}$ \\
\hline 3. & 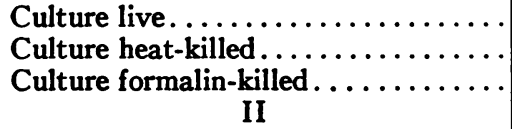 & $\begin{array}{l}0 \\
1: 1280 \\
0\end{array}$ & $\begin{array}{c}0 \\
1: 40 \\
1: 20\end{array}$ & $\begin{array}{c}0 \\
1: \\
040 \\
0\end{array}$ \\
\hline & 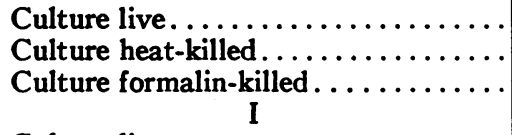 & $\begin{array}{l}\mathbf{0} \\
1: 320 \\
0\end{array}$ & $\begin{array}{c}0 \\
1: 40 \\
0\end{array}$ & $\begin{array}{l}\mathbf{0} \\
1: 160 \\
\mathbf{0}\end{array}$ \\
\hline 4. & $\begin{array}{l}\text { Culture live } \ldots \ldots \ldots \ldots \ldots \ldots \ldots \\
\text { Culture heat-killed } \ldots \ldots \ldots \ldots \ldots \ldots \\
\text { Culture formalin-killed } \ldots \ldots \ldots \ldots \ldots\end{array}$ & $\begin{array}{c}0 \\
1: 80 \\
0\end{array}$ & $\begin{array}{l}0 \\
1: 20 \\
0\end{array}$ & $\begin{array}{c}0 \\
1: 80 \\
0\end{array}$ \\
\hline & 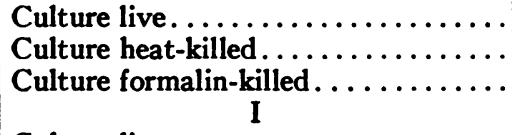 & $\begin{array}{c}0 \\
1: 80 \\
0\end{array}$ & $\begin{array}{l}0 \\
1: 20 \\
0\end{array}$ & $\begin{array}{c}0 \\
1: 80 \\
0\end{array}$ \\
\hline 5. & $\begin{array}{l}\text { Culture live } \ldots \ldots \ldots \ldots \ldots \ldots \ldots \ldots \\
\text { Culture heat-killed } \ldots \ldots \ldots \ldots \ldots \ldots \\
\text { Culture formalin-killed } . \ldots \ldots \ldots \ldots \ldots\end{array}$ & $\begin{array}{l}0 \\
1: \\
040 \\
0\end{array}$ & $\begin{array}{l}\mathbf{0} \\
\mathbf{0} \\
\mathbf{0}\end{array}$ & $\begin{array}{l}0 \\
1: \\
320 \\
0\end{array}$ \\
\hline & 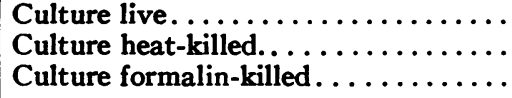 & $\begin{array}{l}0 \\
1: \\
0\end{array}$ & $\begin{array}{l}\mathbf{0} \\
\mathbf{0} \\
\mathbf{0}\end{array}$ & $\begin{array}{l}0 \\
1: \\
0\end{array}$ \\
\hline
\end{tabular}

given the corrected sedimentation rates of patients who had positive agglutinins to hemolytic streptococci. In column B the corrected 
sedimentation rates of a similar group of cases, not showing positive agglutination, are given. All of the sedimentation tests were done according to the method of Rourke and Ernstene (2) and the rate at which the red blood cell count settled is recorded in millimeters per minute.

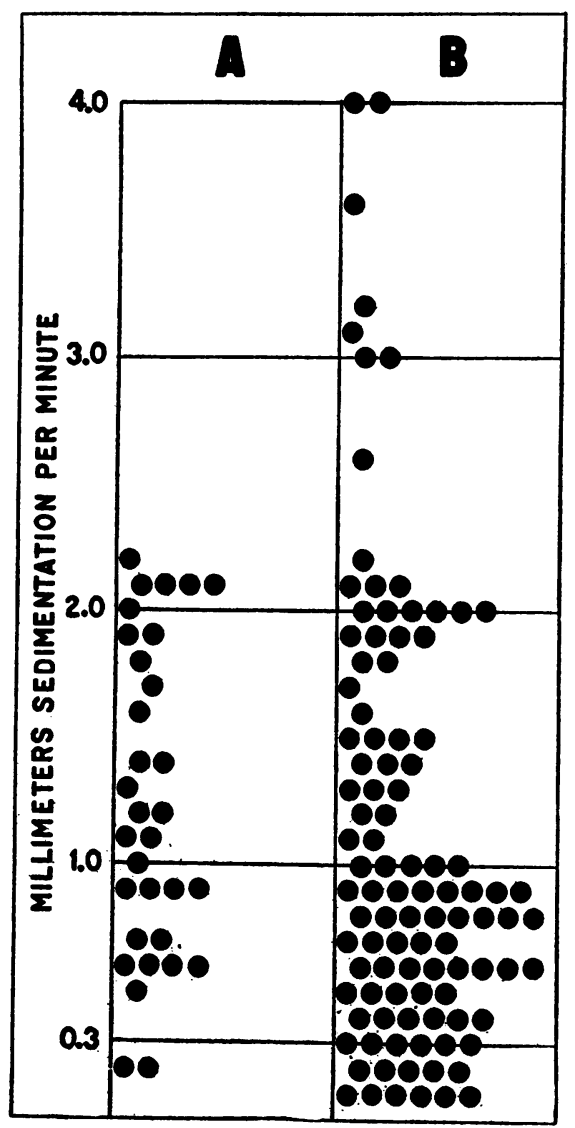

Fig. 1. The Sedimentation Rate and Streptococcal Agglutinins

Each dot in column A represents the sedimentation rate of the red blood cells in a patient with positive streptococcal agglutinins in the blood. Each dot in column $B$, the rate for a patient with negative streptococcal agglutination tests.

From Figure 1 it may be seen that there was no correlation between the rate of sedimentation of the erythrocytes, and the presence of agglutinins in the cases studied. The question was investigated from another viewpoint. Following observations that the sedimentation rate increased after intravenous vaccination of several patients with hemolytic streptococci (see Figure 2), it was of interest to determine whether there was any correlation between the sedimentation rate of the erythrocytes, and 


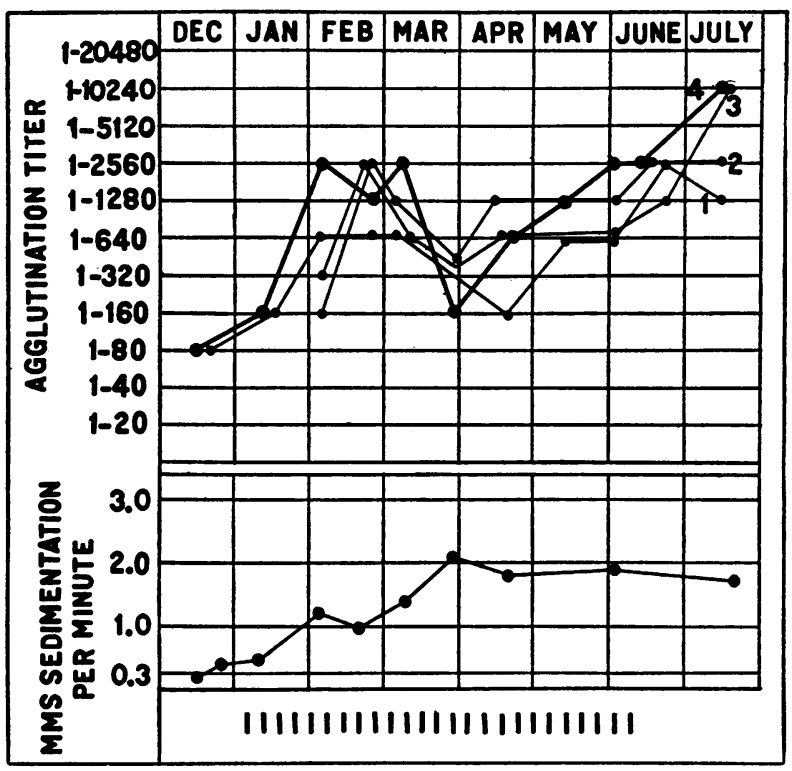

Fig. 2. Chart Showing the Changes in Agglutination Titre of the Blood Serum against Four Strains of Hemolytic Streptococcus and the Corrected Sedimentation Reaction in a Patient with Rheumatoid (Atrophic) Arthritis Who Received Intravenous Injections of HemoLytic Streptococcal Vaccine (Strain 1).

Lines at the bottom of the chart indicate the time and number of injections of vaccine.

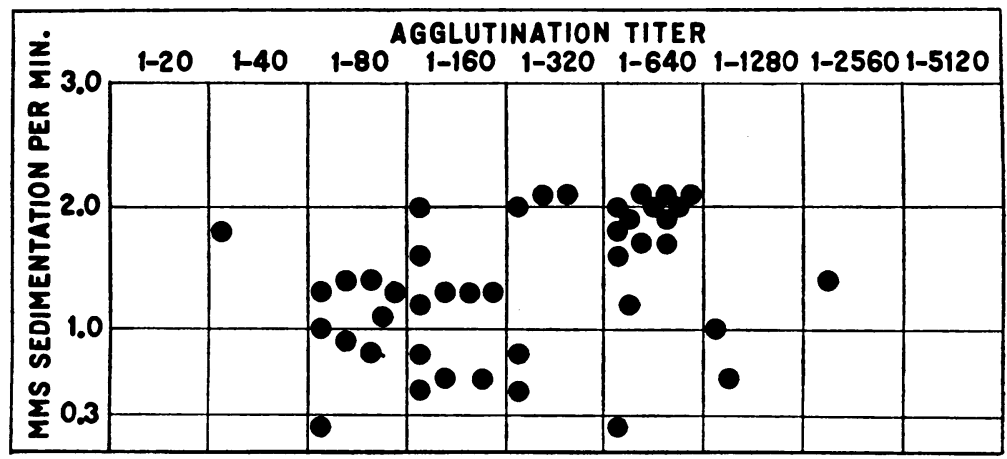

Fig. 3. The Agglutination Titre and the Sedimentation Rate

Each dot represents the agglutination titre and the sedimentation of the red blood cells of a single patient. 
the agglutination titre of the blood serum. Figure 3 shows that there is no such correlation between the two, since sedimentation rates were as rapid in the blood of patients having a low serum agglutinating titre, as in those with a higher titre. There is no doubt, therefore, that the type of agglutination we observed is different from that described by Tillett and Abernethy as occurring during the course of acute infectious diseases due to organisms other than the hemolytic streptococci.

In view of the presence of positive agglutinins in the blood serum of some patients, we tested the reaction of the skin to hemolytic streptococcal nucleoprotein. The results in the patients with positive agglutinins in their blood are summarized in Table 5 .

TABLE 5

Agglutination and skin tests

\begin{tabular}{|c|c|c|c|}
\hline Disease & $\begin{array}{l}\text { Number of } \\
\text { positive } \\
\text { agglutination } \\
\text { tests }\end{array}$ & $\begin{array}{c}\text { Number of } \\
\text { positive } \\
\text { skin } \\
\text { tests }\end{array}$ & Negative \\
\hline $\begin{array}{l}\text { Acute rheumatic fever } \ldots \ldots \ldots \ldots \ldots \ldots \ldots \\
\text { Rheumatoid arthritis } \ldots \ldots \ldots \ldots \ldots \ldots \ldots \ldots \\
\text { Erysipelas. } \ldots \ldots \ldots \ldots \ldots \ldots \ldots \\
\text { Rheumatic heart disease } \ldots \ldots \ldots \ldots \ldots \ldots \ldots \\
\text { Degenerative arthritis } \ldots \ldots \ldots \ldots \ldots \ldots \ldots\end{array}$ & $\begin{array}{r}11 \\
12 \\
4 \\
3 \\
4\end{array}$ & $\begin{array}{l}9 \\
8 \\
3 \\
2 \\
1\end{array}$ & $\begin{array}{l}2 \\
4 \\
1 \\
1 \\
3\end{array}$ \\
\hline
\end{tabular}

Most of the patients with agglutinins in the blood had a positive skin reaction to $0.01 \mathrm{mgm}$. of the nucleoprotein, but it was not so in every case. In a much larger group of patients reported elsewhere (7), a positive skin reaction was found in $\mathbf{4 4}$ per cent of patients without positive agglutinins. It is obvious then that a positive skin reaction to the nucleoprotein may be present without agglutinins being present in the blood, and in some cases agglutinins may be present without a positive skin reaction. The one reaction, then, is not dependent upon the other.

\section{DISCUSSION}

We observed positive streptococcal agglutinins in the blood sera of 54.5 per cent of patients with rheumatoid arthritis, 26.1 per cent with rheumatic fever, 8.6 per cent with rheumatic heart disease, 23 per cent with erysipelas, and 15 per cent with degenerative arthritis. In all of the other sera which was examined from patients with a variety of infections and non-infectious diseases, streptococcal agglutinins were not detected.

Previous findings on the presence of streptococcal agglutinins in the blood sera of patients with rheumatoid arthritis have been made by several investigators, and it may be of advantage to review their results. Clawson and Wetherby (3) have found that all patients with chronic 
arthritis, regardless of clinical type, have agglutinins for the strain of streptococcus used in their tests, but all of their normal patients also had positive agglutinins, the only difference being that the titre of the serum was somewhat higher in the former than in the latter.

Nicholls and Stainsby (4) have shown that streptococcal agglutinins are present in practically all sera of patients with chronic infectious arthritis when their "typical strains" are used. The typical strains are organisms which they have isolated from the blood or joint fluid of patients with infectious arthritis. They also express the opinion that chronic infectious arthritis can be differentiated from degenerative arthritis, and from "chronic polyarthritis following rheumatic fever" by agglutination test. They also state that a close relationship exists between "typical strain" streptococci and the hemolytic streptococci recovered from scarlet fever and erysipelas. Positive agglutinations were observed by them in other diseases when the same organisms were used, but not so frequently, and the titres of the sera were usually lower.

Dawson, Olmstead and Boots (5) have reported the results of a study of the agglutination reactions in rheumatoid arthritis. They found that the blood sera of 67 per cent of 157 patients with typical rheumatoid arthritis possessed the property of agglutinating hemolytic streptococci to a titre varying from 1-20 to 1-2560 or higher. They demonstrated that strains of hemolytic streptococci obtained from scarlet fever, erysipelas and the throats of patients with rheumatic fever were agglutinated by these sera to as high a titre as were the so-called typical strains of Cecil, Nicholls and Stainsby (6). Absorption tests failed to show evidence of specificity for the agglutination reaction to the various strains of hemolytic streptococci examined. Of considerable interest was the fact that the property of the sera obtained from patients with rheumatoid arthritis responsible for the agglutination of hemolytic streptococci was definitely related to the age of the patient and the duration of the disease. That is to say, the longer the duration of the disease and the older the patient, within certain limits, the higher the incidence of positive agglutinins, and the titre of the serum. Furthermore, they express the opinion that there appears to be a relationship between the agglutinins for hemolytic streptococci in patients with rheumatoid arthritis and the natural agglutinins for many bacteria which are present in the blood serum of a wide variety of animal species. They feel, therefore, that the agglutination reaction is highly characteristic both for the bacterial species Streptococcus hemolyticus and the disease rheumatoid arthritis. They recognize, however, that certain attributes of the reaction distinguish it from ordinary agglutination reactions occurring during the course of some specific infectious disease.

It is clear, then, from the work of various investigators, that when agglutinins are present in the sera of patients with arthritis, and other 
disease, they are not strain-specific. Some strains are agglutinated in higher dilutions than others but no one strain predominates.

In drawing conclusions regarding streptococcal agglutinins in general it is necessary to exclude the nonspecific factors described so clearly by Tillett and Abernethy. We feel that the type of agglutination we have observed is due to a process which is different from that described by them. Furthermore, the phenomenon is unlike that which causes rapid sedimentation of the erythrocytes and from the reaction which causes positive skin reactions to the "nucleoprotein" of Streptococcus hemolyticus.

\section{SUMMARY AND CONCLUSIONS}

1. As a result of a study of $\mathbf{1 2 0 5}$ agglutination tests on 332 patients, using four different strains of Streptococcus hemolyticus it was found that 54.5 per cent of the patients with rheumatoid arthritis had positive blood serum agglutinins. Patients with rheumatic fever, rheumatic heart disease, erysipelas and degenerative arthritis also had such agglutinins in $26,9,23$, and 15 per cent of the cases respectively.

2. The positive agglutination tests showed no evidence of strain specificity nor were they correlated with an unusual sedimentation rate of the erythrocytes or positive cutaneous reactions to the "nucleoprotein" of hemolytic streptococci, and the phenomena were different from that causing a rapid sedimentation of the erythrocytes and positive skin reactions to the "nucleoprotein" of hemolytic streptococci.

3. The precise relationship between the presence of streptococcal agglutinins in the blood serum and the tissue responses in patients with rheumatoid arthritis and rheumatic fever must be investigated further.

We wish to acknowledge our thanks to Dr. Stainsby of Cornell University Medical School, Dr. Benjamin White of the Antitoxin Laboratory of the Commonwealth of Massachusetts and Dr. Walter Bauer of the Massachusetts General Hospital for subcultures of strains used in this work. We also thank Miss Marjorie Jewell and Miss Eleanor Fleming for technical assistance.

\section{BIBLIOGRAPHY}

1. Tillett, W. S., and Abernethy, T. J., Bull. Johns Hopkins Hosp., 1932, i, 270. Serological Reactions with Hemolytic Streptococci in Acute Bacterial Infections.

2. Rourke, M. D., and Ernstene, A. C., J. Clin. Invest., 1930, viii, 545. A Method for Correcting the Erythrocyte Sedimentation Rate for Variations in the Cell Volume Percentage of Blood.

3. Clawson, B. J., and Wetherby, M., Ann. Int. Med., 1932, v, 1447. An Experimental Basis for Intravenous Vaccine Therapy in Chronic Arthritis with a Summary of Results Obtained in Patients.

4. Nicholls, E. E., and Stainsby, W. J., J. Clin. Invest., 1931, x, 323. Streptococcal Agglutinins in Chronic Infectious Arthritis. 
5. Dawson, M. H., Olmstead, M., and Boots, R. H., Proc. Soc. Exper. Biol. and Med., 1931, xxviii, 421. Studies on the Etiology of Rheumatoid Arthritis. II. Agglutination Reactions with Hemolytic Streptococci in Rheumatoid Arthritis.

J. Immunol., 1932, xxiii, 187. Agglutination Reactions in Rheumatoid Arthritis. I. Agglutination Reactions with Streptococcus Hemolyticus.

J. Immunol., 1932, xxiii, 205. Agglutination Reactions in Rheumatoid Arthritis. II. The Nature and Significance of Agglutination Reactions with Streptococcus Hemolyticus.

6. Cecil, R. L., Nicholls, E. E., and Stainsby, W. L., Tr. A. Am. Physicians, 1930, xlv, 210. Etiology of Rheumatoid Arthritis.

7. Myers, W. K., Keefer, C. S., and Oppel, T. W., J. Clin. Invest., 1933, xii, 279. Skin Reactions to Nucleoprotein of Streptococcus Scarlatinae in Patients with Rheumatoid Arthritis and Rheumatic Fever. 